\title{
Enyedi humora
}

\section{Enyedi's humour}

\author{
BASSA LÁSZLÓ
}

Az FKI-titkárság nyitott ajtaján középkorú és középtermetű férfi jött be fürge léptekkel, odament a telefonhoz, felvette a félrerakott kagylót, és vidáman beleszólt: Cześcz! Majd hosszasan beszélt lengyelül, nyilván egy ottani kollégával. ĺgy ismertem meg Gyurkát, 1977 első munkanapján.

A beszélgetés bizonyára az újévi jókívánságokra korlátozódott, nekem mindenesetre nagyon imponált, mert néhány hónappal azelőtt jártam Varsóban, a Jazz Jamboreen, ahol még Muddy Waters koncertjét is alkalmam volt hallani. Ottani barátainkkal úgy társalogtunk, hogy ők mondtak valamit lengyelül, én megértettem, oroszul válaszoltam, azt pedig ők értették meg.

Azért csak fúrta az oldalamat, honnan ez a perfekt nyelvtudás. Később, egy beszélgetés során szóba is hoztam a dolgot. Gyurka mondta, hogy ez volt az első idegen nyelv, amit megtanult, jóval előbb, mint akár az angolt vagy a franciát. „Az első külföldi ösztöndíjas utazásom Varsóba vezetett. Az ottani professzor azon nyomban kivitt terepgyakorlatra. A magam részéről szenvedélyesen érdeklődtem a lengyel diáklányok iránt, innen ered a dolog."

Az intézet külügyi föelőadójaként dolgoztam majdnem tíz évig (ahogy egy brit geográfus utóbb megjegyezte, ez roppant kényelmes állás volt, s ebben kétségtelenül igazat kell neki adnom), és sok külföldi társadalom-földrajzossal ismerkedtem meg. Az első nagy esemény a II. Brit-magyar földrajzi szeminárium volt, Szeged és Pécs központokkal. Az előadások a pártbizottság újszegedi kollégiumának egy kisebb termében zajlottak rekkenő hőségben. Az első ülésszak déli fél egy körül már szinte véget ért, amikor a helyi egyetem adjunktusa bejelentette, hogy ő vetítettképes előadással készült, mert udvariatlanság lenne a szervezők részéről, ha a brit geográfusok nem kapnának kellő eligazítást rögtön az elején a dél-alföldi régió természetföldrajzi viszonyairól. Gyurka elnökként vonakodva ugyan, de megadta neki a szót, ugyanakkor kikötötte, hogy „a gyorsabb lebonyolítás kedvéért" o veszi át a tolmács szerepét. Már talán a huszonötödik diánál jártunk, a hallgatóságot az éhségtől ájultság kerülgette, amikor az előadó elérkezett egy végtelenbe nyúló és színes virágokkal tarkított zöld mezőt ábrázoló képhez. Ehhez kb. a következő magyarázatot füzte: ez a májusban, a vegetációs időszak teljében készült felvétel alacsony ártéri, meanderekkel

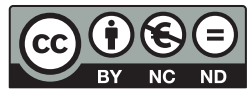


szabdalt, késő holocén felszínt ábrázol, magas talajvízszinttel, itt-ott égeresnyáras galériaerdőkkel, a területet mezőgazdasági tevékenység céljából csupán részben veszik igénybe... és így tovább vagy két percig. Halálos csend támadt, majd Gyurka fordítása hallatszott: Flowers! Mire óriási hahota támadt, asztal- és hátcsapkodással, a rend fölbomlott, mindenki felállt, és a kijárat felé indult.

Enyedi valóban szerette a dolgokat rövidre zárni, a szakmai és társadalmi események alkalmával egyaránt. Tudni kell, hogy vezetése alatt a humánföldrajzi osztály tagjai gyakran szerveztek bulikat. Amikor valamilyen egzotikus külföldi útról tért haza, kértük, tartson rövid élménybeszámolót. Egyszer Caracasból jött meg, és mutatott néhány diát (az egész nem tartott húsz percnél tovább), és zárszóként ennyit tett hozzá: „,...és hát persze a favellák, vendéglátóim figyelmeztettek, nehogy a szegénynegyedek közelébe merészkedjem. Tanácsukat megfogadtam, és ennek köszönhető, hogy itt lehetek körötökben, és voltatok szívesek meghallgatni”. Másik alkalommal a rendezvény jelmezbál formáját öltötte. Gyurka fogyatékkal élőnek álcázta magát, fekete szemüvegben és fehér bottal. Nyakában tábla lógott: „Szegény világtalan vagyok. Vakvezetést vállalok." Volt persze példa arra is, hogy sok alkohol fogyott, és esetenként a dirty dancing stílus sem állt távol tőlünk, mire szemöldökét felvonva megjegyezte: nocsak, turul?

Voltaképpen minden, amit csinált, azt könnyedén csinálta, és nem fetisizálta a dolgokat. A nyelvtudást szinte magától értetődőként kezelte, és ezen a téren is igyekezett bátorítani beosztottait. A már említett szemináriumon mindenkit mozgósítottak, titkárnője, aki a pécsi városnézést vezette, tökéletesen tudott idegen nyelveken, de meglehetősen gátlásos volt. Őt így bíztatta: „Ili, ne azt fordítsd le, amit nem tudsz, hanem azt, amit tudsz!" (Pozitív hozzáállás Enyedi módra). Engem egy előadáson így fogadott: „Nicsak, jöttél okosodni? Ez derék.”

Az okosodás persze fontos dolog, és Gyurka mindig készen állt, hogy tudását, tapasztalatát megossza a fiatalabbakkal. „Egy fontos dolgot jegyezz meg, két francia férfit soha ne szállásolj el egy szobába. Az angolok ennek talán kifejezetten örülnének, de a franciák nem." Ami azt illeti, az akadémia rendszerváltás előtti, a külföldieket a fizetővendég-szolgálat szintjén mozgó elszállásolási rendszere kifejezetten idegesítette. „Kimegyünk Varsóba, és a Fórumban, egy luxusszállóban lakunk. A lengyelek meg idejönnek, és mit kapnak? Az özvegy Guzmicsné mosókonyháját!"

Közismert volt, hogy közel harminc éven keresztül regnáló igazgatónkkal nehezen viselték egymást. Megesett egyszer, hogy Gyurkát nagy sürgölődés fogadta, amikor beért az intézetbe. „Mi történt?” - kérdezi, mire kétségbeesett segélykérés a válasz. „Közeledik a diri neve napja, mit vegyünk neki ajándékba?” „Vegyetek neki néhány igét, hogy a mondatait be tudja fejezni” - ajánlotta Enyedi. Következő igazgatónkkal, egykori beosztottjával viszont szívélyes kapcsolatot ápolt. Amerikából küldött neki képeslapot ezzel a szöveggel: „Szerbusz Pista! Küldök neked egy jövőképet.” A képeslap az arizonai sivatagot ábrázolta, a szokásos tanúhegyekkel. 
Bejárta az egész világot. Japánból jelentette mindnyájunk mulattatására: Nyűttgatyából (Niigata) az utunk Nagyganéjba (Nagano) vezetett. - A rendszerváltás utáni időkben megsokasodtak a bloomingtoni szemináriumok. Hazatérte után élményeiről faggattam, és ő elmondta: az volt a nóvum, hogy idős emigráns, egykori koalíciós politikusok mellett a magyar kutatók legifjabb nemzedéke is képviseltette magát. Egy ifjú nagy reverenciával fordult az egyik nagy öreghez: „Kedves Bátyám, el nem tudja képzelni, micsoda megtiszteltetés, hogy Önnel, a kisgazda összeesküvés egyik oszlopos tagjával van szerencsém találkozni." Mire az csak legyintett: „Lóf...sz volt az, fiam, nem összeesküvés.” Voltak továbbá rendkívül épületes előadások, az egyik „Az első világháborús hangulat változása a katonadalok tükrében” címet viselte. Kezdődött azzal, hogy „Megállj, megállj, kutya Szerbia..., s lett belolle: „Anyám, édesanyám, mért hagytál el engemet?”.

Azért az jóleső érzés, hogy egy ízben kölcsönös poénkodásunk utólag a javamra dőlt el. Még a Népköztársaság útján volt az FKI, s felváltva ebédeltünk a környék vendéglőiben. Mondom Gyurkának: láttad, hogy a Novhét téri Kékes új neve Barátság lett? Lehet, hogy a végén utcát neveznek el Kéthlyről? Mire ő: kétlem...

Bölcsességéből következett öniróniára hajló természete. Egyik akadémiai előadását a zsúfolt kisteremben tartotta, s amikor valaki a nagy hallgatóságot méltatta, ő csak annyit jegyzett meg: a termet is tudni kell megválogatni. Utolsó könyvének előszavában sem tagadta meg magát, amikor azt írta, ez nem a hattyúdala, mert a hattyúnak elég ronda a hangja. De alig egy évtizede, amikor az egyik kolléga nagydoktori esélyeiről kérdeztem közvetlenül a védés előtt, rezignáltan csak annyit mondott: nagy marhaság az egész, de hát nem lehet azzal semmi probléma...

Gyurkával kapcsolatban olyan emlékeket is őrzök, amelyek nem annyira humoros természetéhez kapcsolódnak, amikor családdal néztük meg a retrospektív Erdély Miklós kiállítást a Műcsarnokban, és ott futottunk össze, vagy később, egy vándorgyűlés alkalmával az IC-n Budapesttől Dombóvárig beszélgettünk a közös ismerősökről.

$\mathrm{Az}$ egészben az a legkeserűbb, hogy ezúttal is Enyedi egyik mondása jut eszembe (bár nem tőle származik, de én tőle hallottam): mindnyájan azt hisszük, hogy csak mások halnak meg, mi bezzeg soha. 